\title{
Long-term intravenous administration of carboxylated single-walled carbon nanotubes induces persistent accumulation in the lungs and pulmonary fibrosis via the nuclear factor-kappa B pathway [Corrigendum]
}

Yue Qin, Suning Li, Gan Zhao, et al. Int J Nanomedicine. 2017;12:263-277.

Page 266. In the right column the data range "6 to $15 \mathrm{~nm}$ " should be "5 to $15 \mathrm{~nm}$ ".
Page 267. In Figure 1 Notes "wt\%" should be "wt\%o in SWNTs powder".

Page 268. In Figure 2 Notes " $1 \mathrm{~mL}$ per rat" should be " $1 \mathrm{~mL} / \mathrm{kg}$ body weight".
International Journal of Nanomedicine

\section{Publish your work in this journal}

The International Journal of Nanomedicine is an international, peerreviewed journal focusing on the application of nanotechnology in diagnostics, therapeutics, and drug delivery systems throughout the biomedical field. This journal is indexed on PubMed Central, MedLine, CAS, SciSearch ${ }^{\circledR}$, Current Contents ${ }^{\circledR} /$ Clinical Medicine,

\section{Dovepress}

Journal Citation Reports/Science Edition, EMBase, Scopus and the Elsevier Bibliographic databases. The manuscript management system is completely online and includes a very quick and fair peer-review system, which is all easy to use. Visit http://www.dovepress.com/ testimonials.php to read real quotes from published authors. 